\title{
The real-world problem of care coordination: a longitudinal qualitative study with patients living with advanced progressive illness and their unpaid caregivers
}

\author{
Barbara A Daveson 1*, Richard Harding ${ }^{1}$, Cathy Shipman ${ }^{1}$, Bruce L Mason², Eleni Epiphaniou', Irene J Higginson',

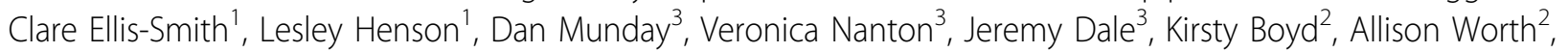 \\ Stephen Barclay ${ }^{4}$, Anne Donaldson ${ }^{2}$, Scott A Murray ${ }^{2}$
}

From Health Services Research: Evidence-based practice

London, UK. 1-3 July 2014

\section{Objectives}

To develop a model of care coordination for patients living with advanced progressive illness and their unpaid caregivers, and to understand their perspective regarding care coordination.

\section{Design}

A prospective longitudinal, multi-perspective qualitative study involving a case-study approach.

\section{Materials and methods}

Serial in-depth interviews were conducted, transcribed verbatim and then analyzed through open and axial coding in order to construct categories for three cases (sites). This was followed by continued thematic analysis to identify underlying conceptual coherence across all cases in order to produce one coherent care coordination model.

\section{Participants}

Fifty-six purposively sampled patients and 27 case-linked unpaid caregivers.

\section{Settings}

Three cases from contrasting primary, secondary and tertiary settings within Britain.

\section{Results}

Coordination is a deliberate cross-cutting action that involves high-quality, caring and well-informed staff, patients and unpaid caregivers who must work in partnership together across health and social care settings. For coordination to occur, it must be adequately resourced with efficient systems and services that communicate. Patients and unpaid caregivers contribute substantially to the coordination of their care, which is sometimes volunteered at a personal cost to them. Coordination is facilitated through flexible and patient-centered care, characterized by accurate and timely information communicated in a way that considers patients' and caregivers' needs, preferences, circumstances and abilities.

\section{Conclusions}

In the midst of advanced progressive illness, coordination is a shared and complex intervention involving relational, structural and information components. Our study is one of the first to extensively examine patients' and caregivers' views about coordination, thus aiding conceptual fidelity. These findings can be used to help avoid oversimplifying a real-world problem, such as care coordination. Avoiding oversimplification can help with the development, evaluation and implementation of real-world coordination interventions for patients and their unpaid caregivers in the future.

${ }^{1}$ Cicely Saunders Institute, King's College London, London, UK

Full list of author information is available at the end of the article 


\section{Authors' details}

${ }^{1}$ Cicely Saunders Institute, King's College London, London, UK. ${ }^{2}$ Centre for Population Health Sciences, Medical School, University of Edinburgh, Edinburgh, UK. ${ }^{3}$ Health Sciences, University of Warwick, Coventry, UK. ${ }^{4}$ The Primary Care Unit, Institute of Public Health, Cambridge, UK.

Published: 7 July 2014

doi:10.1186/1472-6963-14-S2-027

Cite this article as: Daveson et al:: The real-world problem of care coordination: a longitudinal qualitative study with patients living with advanced progressive illness and their unpaid caregivers. BMC Health Services Research 2014 14(Suppl 2):O27.

Submit your next manuscript to BioMed Central and take full advantage of:

- Convenient online submission

- Thorough peer review

- No space constraints or color figure charges

- Immediate publication on acceptance

- Inclusion in PubMed, CAS, Scopus and Google Scholar

- Research which is freely available for redistribution

Submit your manuscript at www.biomedcentral.com/submit
() BioMed Central 